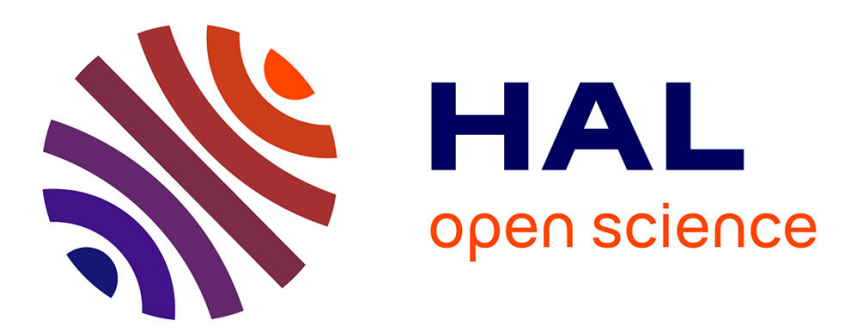

\title{
Impact of a thin plantar orthopaedic insert on posture and locomotion
}

\author{
Carole Puil, Armel Crétual, Anne-Hélène Olivier
}

\section{To cite this version:}

Carole Puil, Armel Crétual, Anne-Hélène Olivier. Impact of a thin plantar orthopaedic insert on posture and locomotion. SOFPEL 2019 - 26ème congrès de la Société Francophone Posture, Équilibre et Locomotion, Dec 2019, Montréal, Canada. hal-02373802

\section{HAL Id: hal-02373802 \\ https://hal.inria.fr/hal-02373802}

Submitted on 25 Feb 2020

HAL is a multi-disciplinary open access archive for the deposit and dissemination of scientific research documents, whether they are published or not. The documents may come from teaching and research institutions in France or abroad, or from public or private research centers.
L'archive ouverte pluridisciplinaire HAL, est destinée au dépôt et à la diffusion de documents scientifiques de niveau recherche, publiés ou non, émanant des établissements d'enseignement et de recherche français ou étrangers, des laboratoires publics ou privés. 


\section{Impact of a thin plantar orthopaedic insert}

\section{on posture and locomotion}

Carole PUIL ${ }^{1,2}$, Armel CRETUAL ${ }^{1}$, Anne-Hélène OLIVIER ${ }^{1}$

Univ Rennes, Inria, M2S - EA 7470, F-35000 Rennes, France ${ }^{1}$

IFPEK $^{2}$

Contact mail: carole.puil@gmail.com

\section{INTRODUCTION}

$\mathrm{EMI}^{\circledR}$ (Medio-Intern Element):

- Podiatrist tool included in insoles

- Correction of postural deficiency:

Contralateral effect of a $3 \mathrm{~mm}$ high $\mathrm{EMI}^{\circledR}$ on $\mathrm{ML}$ displacement of the CoP of healthy participants ${ }^{1}$

- Effect on Eye convergence ${ }^{2}$

$=>$ Lack of evaluation

=> Only on static tasks

\section{AIM AND HYPOTHESIS}

Aim: Evaluate the effect of the $\mathrm{EMI}^{\circledR}$ on posture and locomotion

Hypothesis: effect of EMI ${ }^{\circledR}$ on ML and AP axis and on Ellipse surface

\section{DESIGN AND ANALYSIS}

Participants: 19 healthy volunteers $(9 \hat{0}, 109,27.05$ yrs $( \pm 4.24))$

$\mathrm{EMI}^{\circledR}$ conditions: control (without), under left foot, under right foot

- Static (Force plate ATMI ${ }^{\circledR}$ )

Conditions:

Feet: parallel and $30^{\circ}$ angle

Eyes: open and close

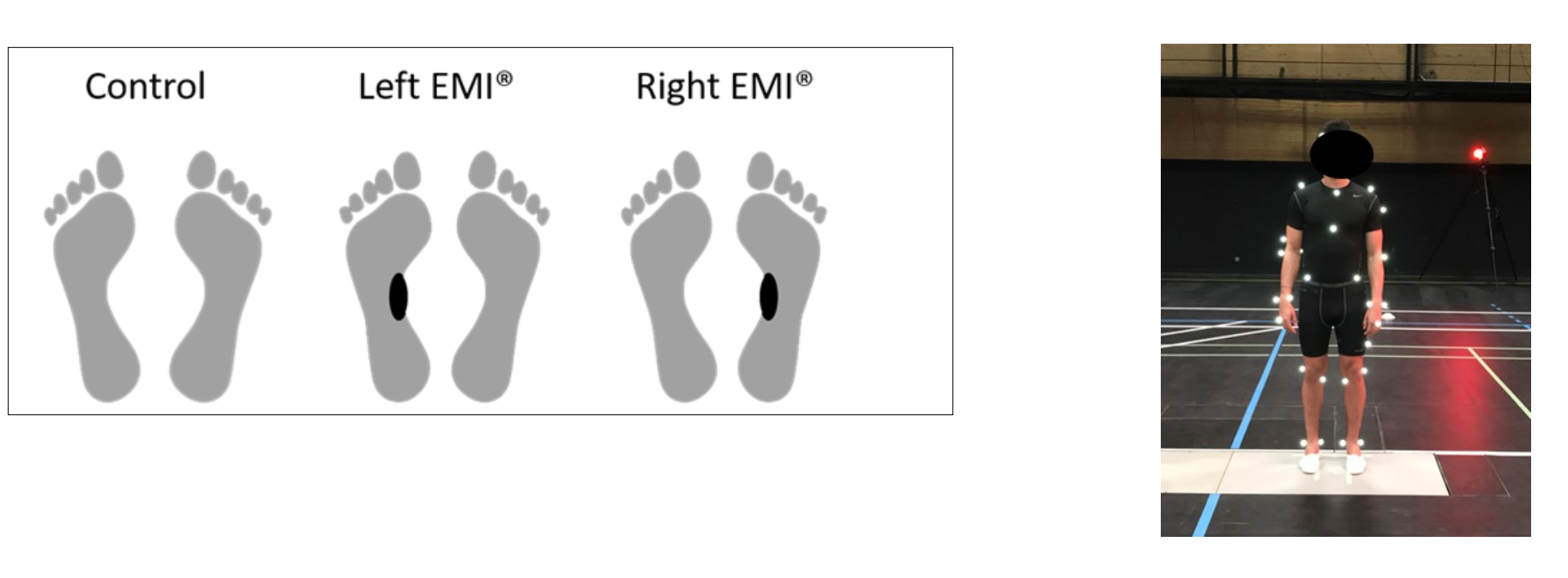

Analysis:

CoP displacement on $\mathrm{ML}$ and $\mathrm{AP}$ axis :

Average position: $\overline{M L} \overline{A P}$

Between trials within subject variability: $\mathrm{BTV}_{\mathrm{AP}}, \mathrm{BTV}_{\mathrm{ML}}$

Within trial within subject variability

Ellipse Area

- Locomotion (Vicon ${ }^{\circledR}$ )

Design based on Podokinetic after rotation (PKAR) protocol ${ }^{3,4}$ (30' of walking stimulation)

Conditions:

Eyes: open and close

Trajectory: straight, turn left $90^{\circ}$, turn right $90^{\circ}$
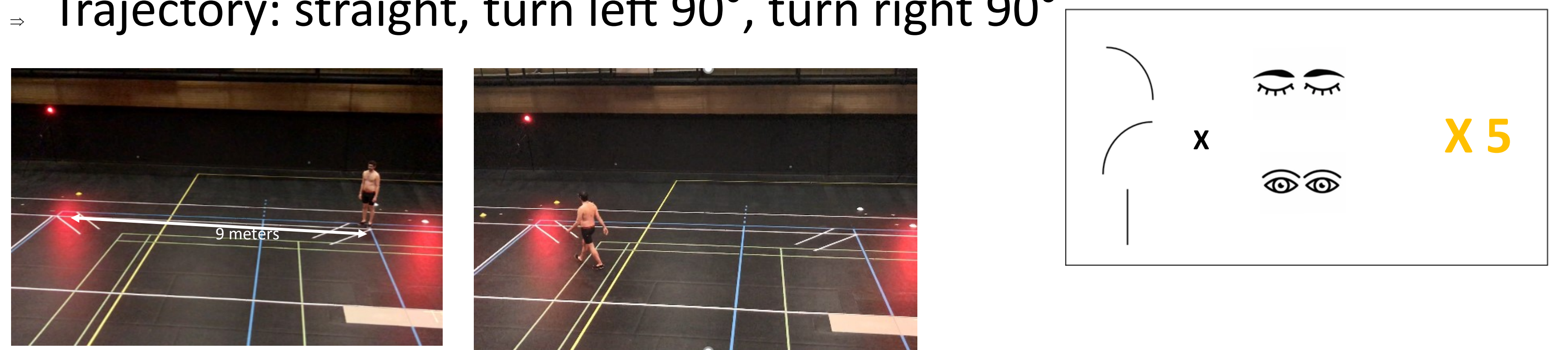

Analysis:

Comparison between the difference in final orientation of locomotion with/without vision, with a $\mathrm{EMI}^{\circledR}$ and without a $\mathrm{EMI}^{\circledR}$

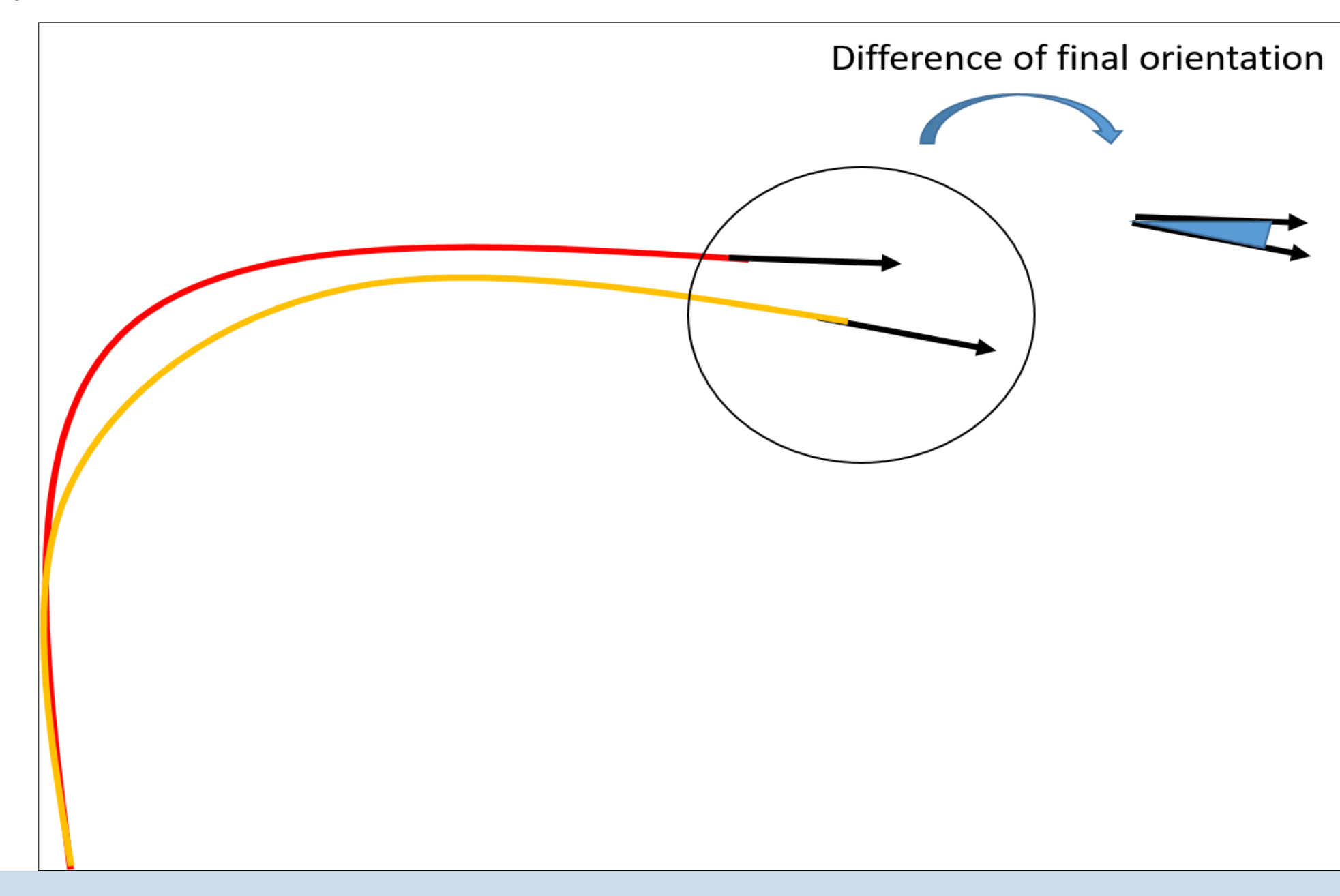

\section{RESULTS}

\section{STATIC:}

Only significant effects on feet position, eye condition and interaction between eye and feet position.

No significant effect of EMI ${ }^{\circledR}$

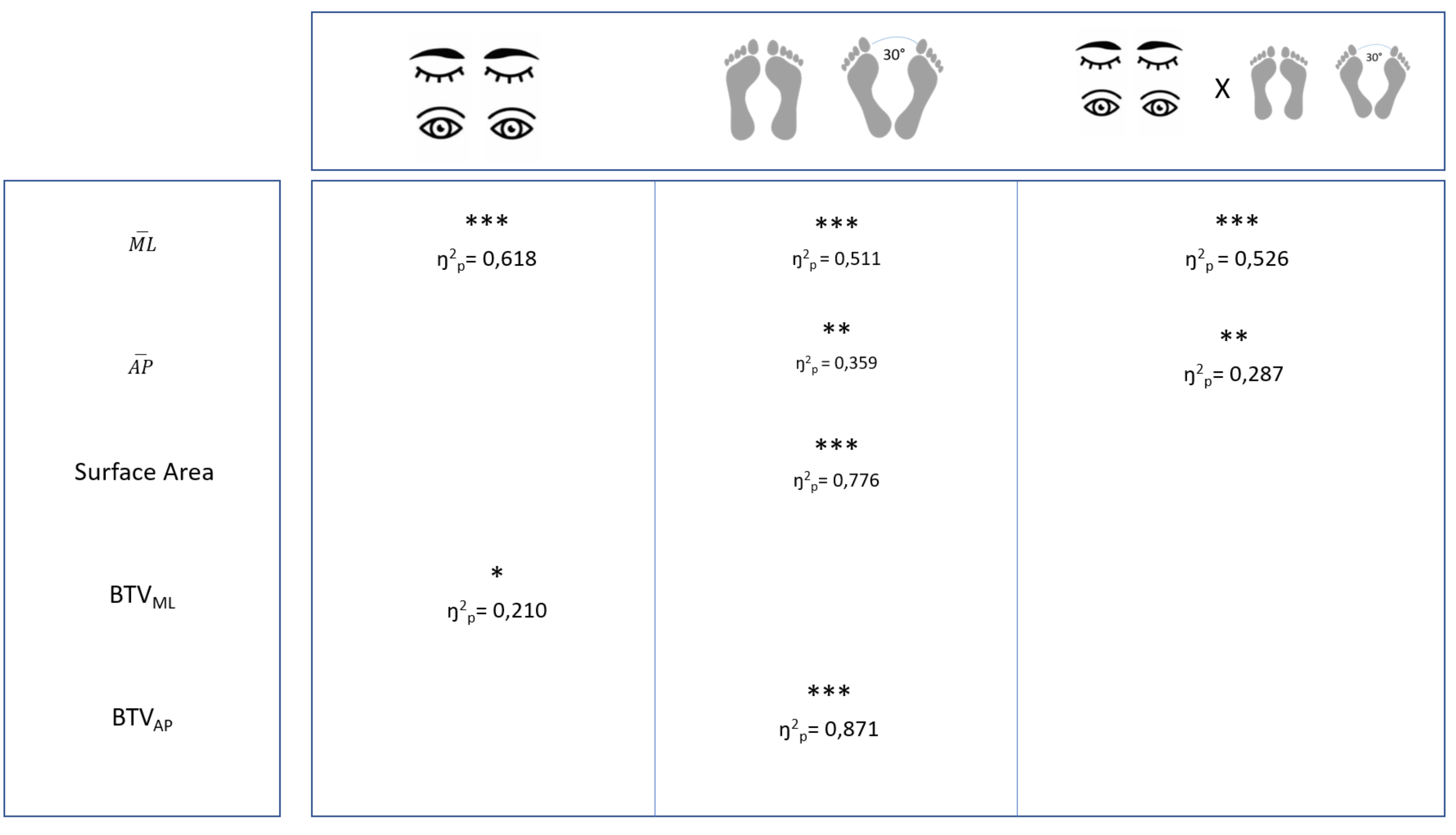

Results of the 4 ways repeted mesures ANOVA (EYExFOOTxEMIxEMIside) Significant effects are represented as well as their size effect $\left(\eta_{p}^{2}\right)$

\section{LOCOMOTION}

No significant effect of $\mathrm{EMI}^{\circledR}$ on the final orientation of the walking

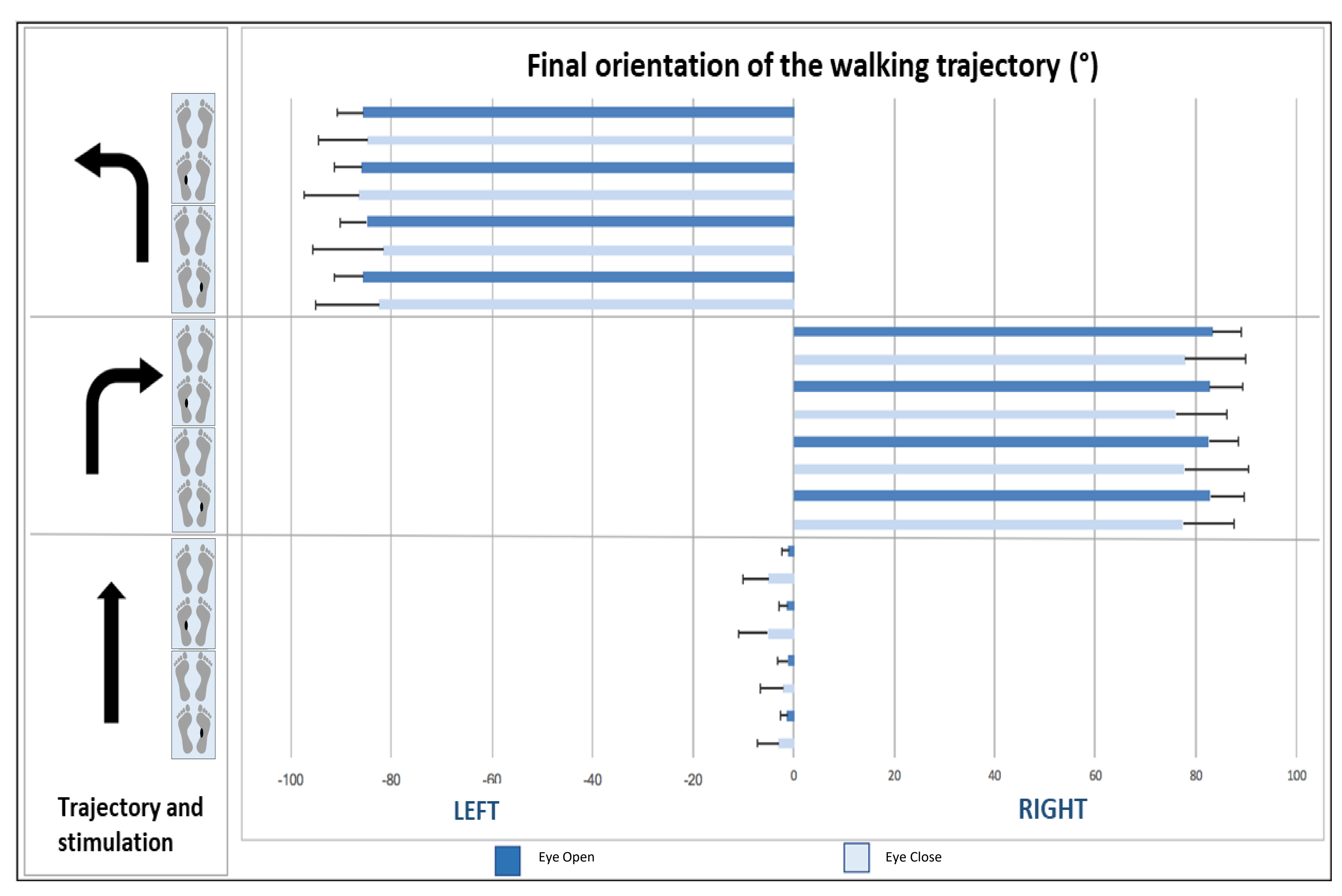

\section{CONCLUSION AND FUTURE WORKS}

Our protocol, involving healthy participants, was not able to show significant effect of $\mathrm{EMI}^{\circledR}$ on posture and locomotion

Feet positions has significant effects on posture: clinical activities have to be standardized to be able to compare CoP movement.

Future works:

- Evaluate population with foot postural deficiency:

More effect of $\mathrm{EMI}^{\circledR}$ on eye vergence on a population with foot postural deficiency ${ }^{2}$

- Normalize the evaluation of foot postural deficiency:

No standardized procedure (compare foam effect ${ }^{2}$ on CoP with Depron ${ }^{\circledR}$ ) 